\title{
ЗЛОЧИННІСТЬ ДЕРЖАВНИХ СЛУЖБОВЦІВ ЯК ЦІЛІСНИЙ КОМПЛЕКСНИЙ ФЕНОМЕН
}

Довбань І. М.

У статmі розкрито проблему злочинності державних службовців як цілісного комплексного феномену. Доведено, що злочинність державних службовців несе в собі підвищену суспільну небезпечність. Саме їі прояви посягають не тільки на інтереси державної служби, а можуть стосуватися інших родових об'єктів злочинів, які вчиняють державні службовці у процесі квазі-службової діяльності, спрямованої на задоволення особистих інтересів, нехтуючи публічними.

Ключові слова: злочини, які вчиняються державними службовцями, злочинність, суспільна небезпечність, інтереси державної служби, особа злочинця.

В статье раскрыта проблема преступности государственных служащих как целостного комплексного феномена. Доказано, что преступность государственных служащих несет в себе повышенную общественную опасность. Именно ее проявления посягают не только на интересь государственной службы, а могут касаться других родовых объектов преступлений, совершаемых государственными служащими в процессе квази-служебной деятельности, направленной на удовлетворение личных интересов, пренебрегая публичными.

Ключевые слова: преступления, совершаемые государственными служащими, преступность, общественная опасность, интересы государственной службы, личность преступника.

The article deals with the problem of public servants criminality as a holistic complex phenomenon. It is proved that public servants criminality carries an increased social danger. Factors of increased social danger of public servants criminality are: 1) the relevant crimes are committed during the performance by public servants the socially significant tasks of the public service, defined in Part 1 of Art. 1 of the Law of Ukraine "On Public Service"; 2) committing crimes by public servants diminishes public confidence in the apparatus of the state, thus eliminating the preventive power of both general and special subjects in combating crime; 3 ) committing such crimes is usually part of a broader so-called "criminal scheme" involving other subjects, often without being prosecuted for non-disclosure. In such circumstances, the multiplicity of crimes and their latency, respectively, are criminal-law and criminological factors of increased social danger of public servants criminality.

Therefore, the current law on criminal liability in Ukraine provides for a number of adverse criminal consequences for persons guilty of committing corruption offenses. It is not only the public service interests that are affected by it, but may also affect other generic objects of crimes committing by public servants in the course of quasi-official activities aimed at satisfying their personal interests and neglecting the public.

In particular, such objects of criminal and law protection are: life and health of a person; will, honor and dignity of a person; election, labor and other personal rights and freedoms of man and citizen; property; sphere of economic activity; the environment; public security; safety of traffic and operation of transport;

Довбань І. М., 2019 public order and morality; sphere of trafficking in narcotic drugs, psychotropic substances, their analogs or precursors, and public health; state secrets, inviolability of state borders, securing conscription and mobilization; authority of state authorities, local self-government bodies, associations of citizens and crimes against journalists; sphere of electronic computers (computers), systems and computer networks and telecommunication networks; business and professional services related to the provision of public services; justice.

Key words: crimes committing by public servants, criminality, public danger, public service interests, person of the offender.

Постановка проблеми та їі актуальність. Злочинність серед державних службовців $\epsilon$ розповсюдженим явищем у всьому світі через найпоширеніший їі вияв корупційну злочинність, з огляду на що на міжнародному рівні (конференції, конгреси, конвенції) вона визнана «епідемією» у більшості країн. Історія цього виду злочинності досить давня, оскільки криється в механізмі задоволення особистих інтересів шляхом зловживання посадовим становищем, виконуючи відповідну функцію держави. За таких обставин можна стверджувати, що злочинність державних службовців виникає з моменту формування апарату держави й поставлення відповідних правовідносин під кримінально-правову охорону шляхом криміналізації відповідних суспільно небезпечних діянь. За таких обставин вказаний вид злочинності набував якісної й кількісної специфіки на різних етапах державотворення країн світу.

Поряд із наявністю відмінностей беззаперечним $\epsilon$ факт схожості злочинів, які вчиняють державні службовці у різних країнах. Це їх підвищена суспільна небезпечність, зважаючи на те, що відповідні злочини вчиняються особами, покликаними протидіяти злочинності загальносоціальними та спеціально-кримінологічними заходами. Це й засвідчує найвищий ступінь правового нігілізму, цинізму й дискредитації апарату держави в очах суспільства. За таких обставин постає потреба в ефективній реалізації у правоохоронній, судовій і кримінально-виконавчій практиці триєдиного принципу невідворотності кримінальної відповідальності, призначення, виконання і відбування покарань державними службовцями, винними у вчиненні злочинів. Тому й чинний Закон України про кримінальну відповідальність передбачає низку несприятливих кримінально-правових наслідків щодо осіб, винних у вчиненні корупційних злочинів, про які, зважаючи на підвищену суспільну небезпечність, йтиметься у цій публікації.

Наведені обставини вимагають відповідного наукового обґрунтування, включаючи вивчення проблеми злочинності державних службовців як цілісного комплексного феномену.

Аналіз останніх досліджень і публікацій. Теоретико-методологічну основу статті склали наукові доробки вітчизняних і зарубіжних вчених, присвячені 
окремим кримінально-правовим i кримінологічним аспектам функціонування державної служби, кримінальній відповідальності державних службовців, кримінологічній характеристиці й запобіганню злочинам, у яких суб'єктом вчинення $€$ державний службовець (службова особа). Серед них праці українських вчених П.П. Андрушка, Л.В. Багрій-Шахматова, В.С. Батиргареєвої, І.Г. Богатирьова, М.Г. Вербенського, П.А. Вороб'я, В.О. Глушкова, В.В. Голіни, Б.М. Головкіна, В.К. Грищука, І.М. Даньшина, С.Ф. Денисова, Т.А. Денисової, О.М. Джужі, В.М. Дрьоміна, О.О. Дудорова, В.П. Ємельянова, А.П. Закалюка, А.Ф. Зелінського, О.Г. Кальмана, В.В. Коваленка, О.Г. Колба, І.М. Копотуна, О.М. Костенка, І.П. Лановенка, О.М. Литвака, О.М. Литвинова, О.А. Мартиненка, П.П. Матишевського, М.І. Мельника, В.А. Мисливого, П.П. Михайленка, А.А. Музики, В.І. Осадчого, А.В. Савченка, В.В. Сташиса, В.Я. Тація, В.О. Тулякова, П.Л. Фріса, М.І. Хавронюка, В.І. Шакуна, Н.М. Ярмиш, С.С. Яценка та інших, а також низки зарубіжних дослідників: О.Я. Асніса, А.Г. Безверхова, Б.В. Волженкіна, А.І. Долгової, С.В. Ізосімова, І.І. Карпеця, В.М. Кудрявцева, В.В. Лунєєва, В.К. Максимова, М.В. Ремізова, О.В. Старкова, О.В. Тарасової, А.В. Шнітєнкова, І.М. Юзефовича та інших.

Поряд із вагомим внеском цих вчених у розроблення теоретико-прикладних засад протидії службовій (посадовій, корупційній) злочинності, питання вивчення злочинності державних службовців як цілісного комплексного феномену не набули широкого висвітлення, що й зумовило формулювання мети цієї публікації.

Метою статті $\epsilon$ вивчення проблеми злочинності державних службовців як цілісного комплексного феномену.

Виклад основного матеріалу. Розглядаючи злочинність державних службовців як цілісний комплексний феномен, автор підтримує позицію зарубіжних вчених, які вважають, що з методологічних позицій ця проблема може також розглядатися як система логічно узгоджених, послідовних, ієрархічно впорядкованих питань, де одні передують іншим і визначають їх зміст. Більше того, на думку зарубіжних вчених Б.А. Аканова, Н.А. Карамзіна, ціна проблеми, навіть якщо вона вирішена, продовжує своє наукове життя, породжуючи нові проблеми [1, с. 17].

Тому в численних дослідженнях зазначається, що посадова (чиновницька, корупційна) злочинність - давня і масова хвороба суспільства, оскільки бере свої корені з утворення держави та іï апарату і має витоки свого «самодетермінування» у прагненні більшості людей до здобуття матеріальних благ (не нехтуючи при цьому протиправними способами), виправдовуючи свої дії відсутністю тяжкої (на думку самих злочинців, оскільки не завдається прямої шкоди життю й здоров'ю інших осіб) шкоди. Історично це призвело до виникнення так званої «білокомірцевої» злочинності, тобто сукупності злочинів, вчинених чиновницьким апаратом, представниками влади, олігархами тощо.

Україна на різних етапах свого державотворення також відчула низку суперечливих процесів, пов'язаних із вчиненням злочинів державними службовцями. Цьому аспекту буде приділено самостійну публікацію.

Натомість варто зазначити, що сучасний етап реформування (розвитку) державної служби України, пов'язаний із прийняттям 10 грудня 2015 року нового Закону
України «Про державну службу» [2], характеризується низкою поступальних процесів, повноцінна реалізація яких ускладнюється таким суспільно небезпечним явищем як злочинність. У свою чергу вияви злочинності можуть мати як загальний характер, так і спеціальний.

Злочинність державних службовців як сукупність вчинених ними протягом визначеного періоду часу злочинів і відповідних суб'єктів належить до спеціальних і характеризується підвищеною суспільною небезпечністю, тобто об'єктивною властивістю описаного у кримінальному законі діяння (дії чи бездіяльності) створювати загрозу або заподіювати шкоду об'єктам кримінально-правової охорони [3, с. 63].

Факторами підвищеної суспільної небезпечності злочинності державних службовців $\epsilon$ :

відповідні злочини, які вчиняються під час виконання державними службовцями соціально значущих завдань державної служби, визначених уч. 1 ст. 1 Закону України «Про державну службу». Тобто, за обставин нехтування інтересами держави на користь власних, переважно корисливих, що свідчить про найвищий рівень правового нігілізму. Та обставина, що особа вчиняє злочин, перебуваючи на посаді державної служби, свідчить про виключну наполегливість винного в його впертому намірі використовувати службове становище для власних цілей. Тому надзвичайна ситуація, за якої державний службовець вчиняє злочин, свідчить про велику суспільну небезпечність особи злочинця. Це повинно бути враховано під час призначення покарання.

Вчинення злочину під час перебування на посаді державної служби свідчить про вперте небажання посадовця сумлінно ставитися до виконання своїх функціональних обов'язків, є зухвалим викликом суспільству, тому закон повинен на це реагувати. Так, закон (Кримінальний кодекс України [4]) встановлює підвищену кримінальну репресію в разі вчинення корупційних злочинів, що виявляється в нормах ст. 45-48, ч. 1 ст. 69, ч. 4 ст. 74, ч. 1 ст. 75, ч. 1 ст. 79, ч. 3 ст. 81, ч. 4 ст. 82 , ч. 4 ст. 86, ч. 3 ст. 87, ч. 2 ст. 91 шляхом застосування конструкції «крім корупційних злочинів» та інших подібних при встановленні менш сприятливих (або шляхом повного їх виключення) обставин застосування тих або інших заохочувальних інститутів кримінального права, а також відповідним чином вибудовуючи систему кримінально-правових санкцій у межах норм Особливої частини закону про кримінальну відповідальність;

- вчинення державними службовцями злочинів зменшує довіру з боку населення до апарату держави, нівелюючи таким чином запобіжні можливості як загальних, так і спеціальних суб'єктів протидії злочинності;

вчинення таких злочинів, як правило, $є$ частиною більш широких так званих «злочинних схем», у яких також беруть участь й інші суб'єкти, часто не будучи притягнутими до кримінальної відповідальності внаслідок невикриття. За таких обставин кримінально-правовими й кримінологічними факторами підвищеної суспільної небезпечності злочинності державних службовців $\epsilon$ множинність злочинів та їхня латентність.

За наведених обставин важливим, на думку автора, $\epsilon$ саме дослідження злочинів, які вчиняють державні службовці, що ґрунтується не стільки на кримінальній статистиці, скільки на вивченні об'єктивної дійсності, безпосереднього спостереження, опитуванні та анкетуванні респондентів, визначенні їх латентності під час 
виконання відповідними суб'єктами функцій держави.

Зазначений підхід дає автору можливість подивитися на проблему злочинності державних службовців i на їі кінцевий продукт - особу, яка вчиняє відповідні злочини, оцінити різні сторони ії поведінки під час обіймання посад державної служби, зокрема суспільну свідомість і психологію; соціальну самоорганізацію, комунікативну та нормативну сфери дотримання норм і правил проходження служби в державних органах. Так, вивчення емпіричних даних [5] засвідчує, що погляд на державну службу та можливості використання службового становища для вчинення злочинів, розміри збитків, латентність цього суспільно небезпечного явища перебувають у кореляційному зв'язку зі становищем державного службовця у відповідній ієрархії (категорії) посад державної служби.

Це підтверджується й дослідженнями українських кримінологів, а саме що державні службовці найвищого рівня і партійні діячі впливають на економічні та соціальні процеси з метою отримання політичної та економічної вигоди, зміцнення свого владного статусу і впливу. Одним із прикладів такої злочинної діяльності $\epsilon$ корупційні дії народного депутата, пов'язані з отриманням неправомірної вигоди від компанії-нерезидента за видобуток бурштину в Україні та легалізація нелегального видобутку бурштину в Житомирській області [6].

Тому й доречним буде використання в цьому разі терміну «феномен» дотично до злочинності державних службовців, оскільки згідно з тлумачним словником, «феномен»- це рідкісне, незвичайне, виняткове явище [7, с. $651 ; 8$, с. 732], яке іноді важко пояснити. Важкість такого пояснення полягає в нерозумінні державними службовцями, які належать до особи відповідного злочинця, а також нехтуванні таким критерієм ефективності державної служби як службова лояльність, яка $\epsilon$ моральною передумовою загальносоціального запобігання злочинам, що вчиняють державні службовці.

Ґрунтуючись на офіційній статистиці за 20162019 роки [5], серед теоретичних і практичних проблем злочинності державних службовців автор виділяє відносно стабільні кількісні показники протягом 2016-2019 років із незначною динамікою змін (як у бік збільшення, так і зменшення): 2016 рік - 164 злочини, 2017 рік - 235, 2018 рік - 202, 2019 рік - 145 злочинів; посягання на різні об'єкти кримінально-правової охорони (життя та здоров'я особи; воля, честь і гідність особи; виборчі, трудові та інші особисті права і свободи людини і громадянина; власність; сфера господарської діяльності; довкілля; громадська безпека; безпека руху та експлуатації транспорту; громадський порядок і моральність; сфера обігу наркотичних засобів, психотропних речовин, їх аналогів або прекурсорів і здоров'я населення; державна таємниця, недоторканність державних кордонів, забезпечення призову та мобілізації; авторитет органів державної влади, органів місцевого самоврядування, об'єднань громадян і злочини проти журналістів; сфера використання електронно-об- числювальних машин (комп'ютерів), систем і комп'ютерних мереж, мереж електрозв'язку; сфера службової та професійної діяльності, пов'язаної з наданням публічних послуг; правосуддя; домінування у їх системі злочинів у сфері службової діяльності та професійної діяльності, пов'язаної з наданням публічних послуг (2016 рік - 83,5\%, 2017 рік - 83,0\%, 2018 рік - 81,7\%, 2019 рік - 84,1\%) й злочину, передбаченого ст. 368 «рийняття пропозиції, обіцянки або одержання неправомірної вигоди службовою особою» (2016 рік - 51,8\%, 2017 рік - 31,5\%, 2018 рік - 33,2\%, 2019 рік - 44,8\%). Невизначеність знань про злочинність державних службовців $\epsilon$ свідченням наявної неузгодженості у кримінальному праві й кримінології та протиріччя між існуючою проблемою у сфері державної служби, її прихованістю (латентністю) та відсутністю потужних кримінологічних досліджень із цієї проблематики.

Висновки. Таким чином, для сфери функціонування державної служби України в умовах дії нового Закону України «Про державну службу» 2015 року характерним $\epsilon$ дуалізм реформування (розвитку), що полягає в низці поступальних процесів і в такому суспільно небезпечному явищі як злочинність. За таких обставин злочинність державних службовців як цілісний комплексний феномен визначається як сукупність вчинених ними протягом визначеного періоду часу злочинів і відповідних суб'єктів, які належить до спеціальних видів злочинності та характеризується підвищеною суспільною небезпечністю.

\section{Література}

1. Аканов Б.А., Карамзин Н.А. Основы научных исследований / под ред. В.М. Мулдахметова. Алма-Ата : Мектен. 1989. 136 с.

2. Про державну службу : Закон України від 10.12.2015 № 889-VIII. Відомості Верховної Ради України. 2016. № 4. СТ. 43.

3. Міжнародна поліцейська енциклопедія: у 10 т. / відп. ред. Є.М. Моісеєв, І.Р. Романенко, В.Я. Тацій, Ю.С. Шемшученко. Київ : Атіка. 2007. T. IV. 1132 с.

4. Кримінальний кодекс України : Закон України від 05.04.2001 № 2341-III. Відомості Верховної Ради України. 2001. № 25-26. Ст. 131.

5. Статистична інформація про осіб, які вчинили кримінальні правопорушення за 2016-2019 роки. Генеральна прокуратура України. URL: https://old.gp.gov.ua/ua/ stst2011.html?dir_id=113898\&libid=100820\#.

6. Турлова Ю.А. Екологічна злочинність в Україні: кримінально-правові та кримінологічні засади протидії : монографія. Київ : Знання України, 2018. 459 с.

7. Новий тлумачний словник української мови: в 3 т., 200000 слів / уклад. В.В. Яременко, О.М. Сліпушко. 2-ге вид., виправ. Київ : Аконіт, 2007. Т. 3. 864 с.

8. Сучасний тлумачний словник української мови: 60000 слів / за заг. ред. д-ра філол. наук, проф. В.В. Дубічинського. Харків : ВД «ШКОЛА», 2007. 832 с.

Довбань І. М., кандидат юридичних наук (м. Київ, Україна) 